\title{
Determination of Some Physiological Parameters of Some Sweet Maize Inbred Lines
}

\author{
Elif Özdemir ${ }^{1}$ and Süleyman Soylu ${ }^{1}$ \\ ${ }^{1}$ Selcuk University; Agriculture Faculty, Crop Science Department, Konya/TURKEY
}

\begin{abstract}
The study was conducted at Selcuk University Agriculture Faculty Crop Science Department in Konya/Turkey during 2013. At the Project during 2013 seeds obtained from 38 sweet maize inbred lines belong to S5 used that have been improved by S.U.Z.F. Crop science Department faculty members. In addition these materials Lümina and Merit hybrid maize varieties were used as standards. The study was conducted according to "Augmented Experimental Design" as four blocks at S.U.Z.F. Crop Science Department Prof. Dr. Abdulkadir AKCIN experimental area. Trials were settled for a year during 2013. When at the blocks all inbred lines were exemplify with an unrepeated line, standard hybrid maize varieties were repeated at all blocks. Stomatal conductance, chlorophyll content, photosynthetic efficiency, proline and MDA level values used to determine physiological parameters of lines. All analyses were done at 5 plants at all lines and standards during tasseling time. While Stomatal conductance values of sweet maize inbred lines varies between 31, 19 mmol. $\left(m^{2} s^{1}\right)^{-1}(4.1 .5)$ to 4, 56 mmol. $\left(\mathrm{m}^{2} \mathrm{~s}^{1}\right)^{-1}$ (4.26.2), chlorophyll content of lines changes between 57, 28 spad (4.5.2) to 34, 99 spad (4.16.2). Photosynthetic efficiency of lines ranges between 0,835 fv.fm-1 (4.16.2) to 0,732 fv.fm-1 (4.6.4). Proline

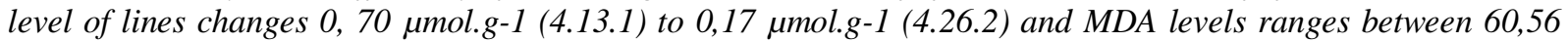
nmol.g-1 (4.1.3) to 29,34 nmol.g-1 (4.3.2). As a result of the study a lot of morphological and phenological characteristics of lines were determined comparatively with hybrid maize varieties, at this way an important variation is detected with all of those identified parameters. It can be told that those lines can be source of successful hybrid maize varieties in the future.
\end{abstract}

Keywords: Sweet Corn, Inbred Lines, Physiology, Malondialdehyde, Proline

\section{Introduction}

Maize is a plant that is very suitable for cultivating agricultural areas intensively, can use solar radiation very efficiently, can produce high level dry matter and grain and can be used multipurposes. Maize culture can be done all parts of our country because of its' wide adaptation capability and high yield potential [1]. Maize that provides benefits of country economy in all respects is a hot climate crop. Maize has an important place between all crop harvesting areas in our country with harvesting areas of 6586450 decares, with production of 5950000 tones and with yield of $907 \mathrm{~kg} \mathrm{da}^{-1}$. Maize cultivating areas of Turkey have high yield and production values [2].

Although maize known well produced wide areas in Turkey, sweet maize which is one of the important maize variety groups has no production and consumption statistical values [3]. Sweet maize (Zea mays saccharata Sturt.) that is one of the maize variety groups is cultivated especially USA intensively. When other maize variety groups are used animal feeding and industry with different aims, sweet maize can be used fresh, frozen and as canned food directly for human nutrition. Last years sweet maize consumption of Turkey increases day by day especially touristic areas and cosmopolite cities [4]. Some parts of products of maize, that' $\mathrm{s}$ fresh green parts and grains use for human and animal nutrition, use as raw material for producing of starch base sugar industry [5]. Local hybrid maize varieties are developed in our country every year and foreign base maize varieties also take part of planting areas in Turkey. To get own place of maize in Turkey' s planting areas, developed and developing maize varieties adaptation studies should be repeated and the properties of generations that can be transferred to other generations should be detected and recorded. One of the most important aim of maize breeding is to produce inbred parents that can form hybrid genotypes which can be used for trade. Measuring a crop's physiological parameters provides information for interpreting its response to the environment. Remote sensing quickly becoming recognized as a valuable tool that has the potential to assess a wide variety of physiological properties over a large area in a short amount of time [6]. Parameters that will be detected at this study will express values of lines according to physiology and will light the reason of the line becoming at the selection program at this way. To improve sturdy hybrid maize varieties, it is necessary to 
improve strong lines. Aim of this study is determination of sturdy lines by identifying lines properties by using physiological parameters.

\section{Materials And Methods}

\subsection{Materials}

At the project seeds belong to 38 sweet maize inbred lines obtained from S5 stublines whose inbreeding programs have been going on, developed by Prof. Bayram SADE and Prof. Süleyman SOYLU from Selcuk University Agriculture Faculty Crop Science Department Konya/Turkey were used. In addition to these materials Lümina and Merit hybrid maize varieties used as standards.

\subsection{Methods}

The study was conducted at S.U.A.F. Crop Science Department Prof. Dr. Abdulkadir AKCIN experimental area as four blocks according to "Augmented Experimental Design". The trials were settled down for a year during 2013. Also each line were represented unrepeatedly as a row, standard hybrid maize varieties took part repeatedly at each block. The soil of experimental area was treated, weeds were removed mechanically and seed bed was prepared. Seeds obtained from inbred lines were sowed at the second week of May. Each inbred line was sowed by hand to $5 \mathrm{~m}$ rows. Between of rows was set as $70 \mathrm{~cm}$, between of plants was set $25 \mathrm{~cm}$. The experimental area was fertilized according to soil analyses results as $18 \mathrm{~kg} / \mathrm{da} \mathrm{N}$ and $11 \mathrm{~kg} / \mathrm{da}_{2} \mathrm{O}_{5} .4 \mathrm{~kg}$ of $\mathrm{N}$ and all of P [DAP (16 N-46 P2O5)] were treated with sowing. Rest of $\mathrm{N}$ was treated during second weed control and progressive developing stages at the form of ammonium nitrate $(\% 33 \mathrm{~N})$. Blocks were designed with $1 \mathrm{~m}$ intervals. Measurements and analysis were done at 5 plant of each row during "Tasseling Time". The measurements and analysis that were done at inbred lines were summarized below.

\section{Measurements And Analysis}

\subsection{Stomatal conductance}

Stomatal conductance was measured with porometer during "Tasseling Time" at five plants of each rows and recorded [7].

\subsection{Chlorophyll content}

This parameter is measured with Spadmeter Spad-502 during "Tasseling Time" at five plants of each row and results recorded [8].

\subsection{Photosynthetic efficiency}

This parameter was also determined at five plants of each rows as others. Before measurement surface of treatment area of leaves were closed for 30 minutes. No changeable basal chlorophyll fluorescence (Fo), changeable fluorescence $(\mathrm{Fv})$, maximum fluorescence induction $(\mathrm{Fm})$ and changeable fluorescence/maximum fluorescence $\left(\mathrm{fv} \cdot \mathrm{fm}^{-1}\right)$ rate were determined with "Plant Efficiency Analyzer" (PEA) (Hansatech Instruments Ltd.) and results were recorded [7].

\subsection{Proline}

Free proline content determination was done according to [9]. $520 \mathrm{~nm}$ absorbance of toluene fraction that was aspired from liquid phase detected with spectrophotometer, proline concentration was calculated from calibration curve and recorded as fresh weight $\mu$ mol. proline $\mathrm{g}^{-1}$.

\subsection{Lipid peroxidation}

This parameter was detected according to the method which was defined by [10], according to this method MDA level that occurs final of TBAR reaction was calculated. Absorbance changes between 532 to $600 \mathrm{~nm}$ was measured to determine the activity and recorded.

\subsection{Statistical analyses and assessment}

Variances obtained from research were analyzed according to "Augmented Experimental Design" with Jump 5.0.1 program. 


\section{Results And Discussion}

\subsection{Stomatal conductance}

Variance analysis values of control varieties were given Table 1. Merit one of the control varieties used at the study had the highest stomatal conductance value $\left(7,97 \mathrm{mmol} .\left(\mathrm{m}^{2} \mathrm{~s}^{1}\right)^{-1}\right.$, the other one Lümina followed it with value of mmol. $\left(\mathrm{m}^{2} \mathrm{~s}^{1}\right)^{-1}$.

TABLE I: Variance Analysis Table of Control Varieties Stomatal Conductance Values

\begin{tabular}{lcccc}
\hline \hline Variation Source & Degree of Freedom & Sum of Square & Mean Square & $\mathrm{F}$ \\
\hline Between Blocks & 2 & 2,48 & 1,241 & 1,2985 \\
Between Control Varieties & 2 & 12,40 & 6,198 & 6,4876 \\
Varieties & 36 & 1046,22 & 29,062 & 30,4202 \\
Error & 3 & 2,87 & 0,955 & - \\
General & 43 & 1063,97 & 37,455 & - \\
\hline \hline
\end{tabular}

When lines compared with control varieties it is recorded that $4.1 .5\left(31,19 \mathrm{mmol} .\left(\mathrm{m}^{2} \mathrm{~s}^{1}\right)^{-1}\right), 4.2 .3(21,19$ mmol. $\left.\left(\mathrm{m}^{2} \mathrm{~s}^{1}\right)^{-1}\right)$ and $4.14 .2\left(18,22 \mathrm{mmol} .\left(\mathrm{m}^{2} \mathrm{~s}^{1}\right)^{-1}\right)$ coded lines left behind standards significantly. 4.6.3 (4,69 mmol. $\left.\left(\mathrm{m}^{2} \mathrm{~s}^{1}\right)^{-1}\right), 4.6 .4\left(4,67 \mathrm{mmol} .\left(\mathrm{m}^{2} \mathrm{~s}^{1}\right)^{-1}\right)$ and 4.26.2 $\left(4,56 \mathrm{mmol} .\left(\mathrm{m}^{2} \mathrm{~s}^{1}\right)^{-1}\right)$ coded lines were formed the lowest values group and lagged behind of standards. Values obtained from this parameter changed between 31,19 mmol. $\left(\mathrm{m}^{2} \mathrm{~s}^{1}\right)^{-1}$ and $4,56 \mathrm{mmol} .\left(\mathrm{m}^{2} \mathrm{~s}^{1}\right)^{-1}$. Stomatas are very sensitive cell structures that provide contact of plant with atmosphere directly are affected too much from environmental conditions. Being stomatal conductance values between normal limits show that plant is compatible with environmental factors and photosynthetic reactions are going on well [11]. When results obtained from this trial were investigated it is detected that stomatal conductance of some lines [4.1.5 $\left(31,19\right.$ mmol. $\left.\left(\mathrm{m}^{2} \mathrm{~s}^{1}\right)^{-1}\right)$; 4.2.3 $\left(21,19 \mathrm{mmol} .\left(\mathrm{m}^{2} \mathrm{~s}^{1}\right)^{-1}\right) ; 4.14 .2(18,22$ mmol. $\left.\left.\left(\mathrm{m}^{2} \mathrm{~s}^{1}\right)^{-1}\right)\right]$ are higher than standards. Based of these results it can be told that those lines adaptation capability to their cultivating areas is better than others. [7] reported that progressive stages of plant growth photosynthesis, transpiration rates and stomatal conductance are decreases significantly. Trial area was irrigated whenever need but Middle Anatolia is a geographical region that water resources are limited, humidity is not enough and this cause water lose by transpiration. So high stomatal conductance level of those lines means that those lines used current water efficiently. Those lines photosynthetic efficiency values became higher than much of other lines because they didn't have to be restrict their stomatal activity because of their efficiently water usage capability $\left[4.1 .5\left(0,818 \mathrm{fv}_{\mathrm{fm}}{ }^{-1}\right) ; 4.2 .3\left(0,808 \mathrm{fv} \cdot \mathrm{fm}^{-1}\right) ; 4.14 .2\left(0,818 \mathrm{fv} . \mathrm{fm}^{-1}\right)\right]$. Some lines profiting by current water more efficiently than others show that they can utilize water enough that is used as electron source at photosynthetic reactions. High stomatal conductance values of lines means plants have enough $\mathrm{CO}_{2}$ at their structure that is used as $\mathrm{C}$ source at photosynthetic reactions. [12] found similar results also [13]. According to their study there is a positive correlation between grain yield, photosynthesis rate and stomatal conductance values. Stomatal conductance values are determined calculating of gas exchange level. High stomatal conductance values provides low leaf temperature, at this way it can be told that high stomatal conductance values provides low temperature of plant vegetation [14][12].

\subsection{Chlorophyll content}

Variance analysis values of control varieties were given Table 2 below. The control variety Lümina had the highest chlorophyll content value (51,39 spad), Merit followed it with value of 50,63 spad.

TABLE II: Variance Analysis Table of Control Varieties Chlorophyll Content Values

\begin{tabular}{lcccc}
\hline \hline \multicolumn{1}{c}{ Variation Source } & Degree of Freedom & Sum of Square & Mean Square & F \\
\hline Between Blocks & 2 & 894,78 & 447,390 & 1,2263 \\
Between Control Varieties & 2 & 35,74 & 17,870 & 9,1775 \\
Variety & 36 & 930,53 & 25,848 & 1,5281 \\
Error & 3 & 35,74 & 11,915 & - \\
General & 43 & 1896,79 & 503,023 & - \\
\hline \hline
\end{tabular}


When lines compared with varieties it is observed that $4.1 .5(31,19 \mathrm{spad}), 4.2 .3(21,19 \mathrm{spad})$ and 4.14.2 $(18,22 \mathrm{spad})$ coded lines left standards [Lümina (6,79spad); Merit $(7,97 \mathrm{spad})$ ] behind clearly. When lines compared with control varieties it is recorded that 4.5.2 (57,28 spad) and 4.3.1(51,58 spad) coded lines left behind standards significantly. 4.27 .3 (36,13 spad), 4.27.1 (35,59 spad) and 4.16.2 (34,99 spad) coded lines were formed the lowest values group and lagged behind of standards. Values obtained from this parameter changed between 57,28 spad and 34,99 spad. Photosynthetic reactions are carried out at thylakoid membranes of granas at chloroplasts. Those structures include high level of chlorophyll. Chlorophylls are molecules that photosynthesis carries out, so meaning of having high level chloroplast is high level of photosynthetic activity. At this study some of lines chlorophyll content [4.5.2 (57,28spad); 4.3.1(51,58 spad)] are much more than standard varieties [Lümina (51,39 spad); Merit (50,63 spad)]. At this way it can be told that photosynthetic activity of those lines are higher than others. Chlorophyll fluorescence values of those lines became higher than some other lines also [4.5.2 (0,790 spad); 4.3.1 (0,791 spad)]. [15] reported that net photosynthetic rate values obtained chlorophyll meter have maximum relations with net photosynthetic rate. [12] reported that leaf chlorophyll content shows photosynthetic capacity. Using spadmeter is a cheap, fast and reliable method for detecting chlorophyll content and nitrogen level. Most suitable time using chlorophyll meter is the period after flowering.

\subsection{Photosynthetic efficiency}

Variance analysis table of control varieties were given at Table 5. When photosynthetic efficiency value of Lümina was $0,795 \mathrm{fv} . \mathrm{fm}^{-1}$, photosynthetic efficiency value of the other control variety Merit became $0,801 \mathrm{fv} . \mathrm{fm}^{-}$ 1

TABLE III: Variance Analysis Table Belongs To Photosynthetic Efficiency Values of Control Varieties

\begin{tabular}{lcccc}
\hline \hline \multicolumn{1}{c}{ Source of Variation } & Degree of Freedom & Sum of Square & Mean Square & F \\
\hline Between Blocks & 2 & 0,00013 & 0,00007 & 0,1892 \\
Between Control Varieties & 2 & 0,00062 & 0,00031 & 0,8832 \\
Variety & 36 & 0,02300 & 0,00064 & 1,8095 \\
Error & 3 & 0,00106 & 0,00035 & - \\
General & 43 & 0,02481 & 0,00136 & - \\
\hline \hline
\end{tabular}

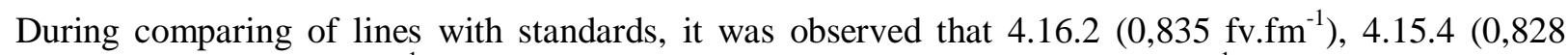
$\left.\mathrm{fv} . \mathrm{fm}^{-1}\right)$ and $4.28 .2\left(0,821 \mathrm{fv}^{-\mathrm{fm}^{-1}}\right)$ coded lines lagged behind of Merit $\left(0,801 \mathrm{fv} . \mathrm{fm}^{-1}\right)$ that got the highest photosynthetic efficiency value of standards. Whereas $4.12 .1\left(0,752 \mathrm{fv} . \mathrm{fm}^{-1}\right), 4.21 .1\left(0,749 \mathrm{fv}^{-\mathrm{fm}^{-1}}\right)$ and 4.6 .4 $\left(0,732 \mathrm{fv} \cdot \mathrm{fm}^{-1}\right)$ coded lines lagged behind of Lümina $\left(0,795 \mathrm{fv} / \mathrm{fm} \mathrm{fv} \mathrm{fm}^{-1}\right)$ whose photosynthetic efficiency value became the lowest of standards. Other values obtained from the parameter changed between them. [8] reported that photosynthetic efficiency is a parameter that is used to determine of plant high temperature tolerance under high temperature stress areas. At the study chlorophyll fluorescence values of some lines $\left[4.16 .2\left(0,835 \mathrm{fv} . \mathrm{fm}^{-1}\right)\right.$;

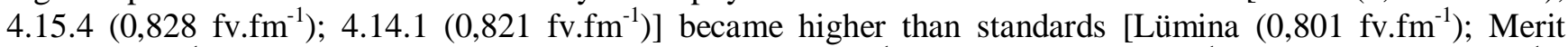
$\left.\left(0,795 \mathrm{fv} \cdot \mathrm{fm}^{-1}\right)\right]$. Those lines chlorophyll [4.16.2 (34,99 fv.fm $\left.\left.{ }^{-1}\right) ; 4.15 .4\left(40,29 \mathrm{fv} \cdot \mathrm{fm}^{-1}\right) ; 4.14 \cdot 1\left(46,43 \mathrm{fv} \cdot \mathrm{fm}^{-1}\right)\right]$ content also became higher than some other lines similarly. Values obtained from this parameter supported these values also. [16] reported that at the study they conducted Roman, determined some physiological characteristics like leaf occurrence, photosynthetic efficiency, stub occurrence and chemical composition at some hybrid maize groups of FAO 200-300, determined that hybrids whose those characteristics were better had yield more than 7,5 tones ha ${ }^{-1}$.

\subsection{Proline}

Variation analysis table of control varieties were given table 4.The highest proline content from standards were obtained from Lümina with value of $0,34 \mu \mathrm{mol} . \mathrm{g}^{-1}$, Merit followed it with value of $0,27 \mu \mathrm{mol} . \mathrm{g}^{-1}$. While lines compared with standards proline content of 4.13.1 $\left(0,70 \mu \mathrm{mol} . \mathrm{g}^{-1}\right), 4.25 .1\left(0,69 \mu \mathrm{mol} . \mathrm{g}^{-1}\right)$ and $4.4 .3(0,65$ $\left.\mu \mathrm{mol} . \mathrm{g}^{-1}\right)$ coded lines became higher than standards, proline content of 4.24.2 $\left(0,23 \mu \mathrm{mol} . \mathrm{g}^{-1}\right), 4.1 .2(0,18$ $\left.\mu \mathrm{mol} . \mathrm{g}^{-1}\right)$ and 4.26.2 $\left(0,17 \mu \mathrm{mol} . \mathrm{g}^{-1}\right)$ coded lines became lower than proline content of Merit $\left(0,27 \mu \mathrm{mol} . \mathrm{g}^{-1}\right)$ whose proline content is the lower of standards. General proline content of values changed between $0,70 \mu \mathrm{mol} . \mathrm{g}$ 
${ }^{1}$ and $0,17 \mu \mathrm{mol} . \mathrm{g}^{-1}$. It was thought that proline was an osmolit that protects cell structures during osmotic stress conditions. But nowadays it is known that proline accumulation at plants is effective at different ways' to stress tolerance [17][18]. Proline is a molecular chaperon that protects protein and organizes different enzyme activities. Nowadays some of researchers reported that proline is an antioxidant which prevents ROS (Reactive Oxygen Species) and $\mathrm{O}_{2}{ }^{1}$ (Singlet Oxygen) activity [17][18]. Lines rich proline content means that those lines can be used to develop antioxidant rich varieties. Those varieties can be tolerant towards stress factors.

TABLE IV: Variation Analysis Table of Controls' Proline Values

\begin{tabular}{lcccc}
\hline \hline \multicolumn{1}{c}{ Variation Source } & Degree of Freedom & Sum of Square & Mean Square & F \\
\hline Between Blocks & 2 & 0,0010 & 0,0005 & 0,0000 \\
Between Varieties & 2 & 0,0270 & 0,0135 & 0,4183 \\
Variety & 36 & 0,8190 & 0,0228 & 0,6878 \\
Error & 3 & 0,0993 & 0,0331 & - \\
General & 43 & 0,9463 & 0,0699 & - \\
\hline \hline
\end{tabular}

\subsection{Lipid peroxidation (MDA)}

Variance analysis table of control group was given at Table 5. The highest MDA level was obtained from Merit (45,68 nmol. $\left.\mathrm{g}^{-1}\right)$ and Lümina was followed it with value of 33,03 nmol.g ${ }^{-1}$.

TABLE V: Variance Analysis Table of Control Varieties MDA (Malondialdehyde) Values

\begin{tabular}{lcccc}
\hline \hline \multicolumn{1}{c}{ Variation Source } & Degree of Freedom & Sum of Square & Mean Square & F \\
\hline Between Blocks & 2 & 0,0001 & 0,0001 & 0,0000 \\
Between Control Varieties & 2 & 336,8171 & 168,4086 & 55,7302 \\
Variety & 36 & 1623,3648 & 45,0935 & 14,9225 \\
Error & 3 & 9,0656 & 3,0219 & - \\
General & 43 & 1969,2476 & 216,5240 & - \\
\hline
\end{tabular}

While lines were examined it was seen that $4.1 .3\left(60,56 \mathrm{nmol.g}{ }^{-1}\right), 4.3 .1\left(59,27 \mathrm{nmol.g}{ }^{-1}\right)$ and $4.27 .3(52,31$ nmol. $\left.\mathrm{g}^{-1}\right)$ coded lines got highest values opposite to $4.24 .3\left(31,66 \mathrm{nmol} . \mathrm{g}^{-1}\right), 4.18 .1\left(31,15 \mathrm{nmol} . \mathrm{g}^{-1}\right)$ and 4.3 .2 $\left(29,34\right.$ nmol. $\left.\mathrm{g}^{-1}\right)$ coded lines that had lowest values. While comparing lines with standards, it was seen that 4.1.3 $\left(60,56 \mathrm{nmol} . \mathrm{g}^{-1}\right), 4.3 .1\left(59,27 \mathrm{nmol} . \mathrm{g}^{-1}\right)$ and $4.27 .3\left(52,31 \mathrm{nmol} \cdot \mathrm{g}^{-1}\right)$ coded lines left standards behind for this parameter. 4.24.3 (31,66 nmol. $\left.\mathrm{g}^{-1}\right)$, 4.18.1 (31,15 nmol.g $\left.{ }^{-1}\right)$ and 4.3.2 (29,34 nmol.g $\left.{ }^{-1}\right)$ coded lines' MDA level generated lowest values. Other values changed between $60,56 \mathrm{nmol} / \mathrm{g}$ and $29,34 \mathrm{nmol} . \mathrm{g}^{-1}$. Lipid peroxidation level that changes by time can be explained as low antioxidative defense system performance [19]. [20] reported that proline (an antioxidant) content increase according to drought at the study of developing drought tolerance bread wheat cultivars. At the same study it was also told that increased lipid peroxidation level effect antioxidative defense system negatively. When datas examined at this way, it can be told that lines whose MDA level is low can be more tolerated towards stress factors [4.1.3 (60,56 nmol.g $\left.{ }^{-1}\right) ; 4.3 .1\left(59,27 \mathrm{nmol}^{-1} \mathrm{~g}^{-1}\right) ; 4.27 .3$ $\left.\left(52,31 \mathrm{nmol} \cdot \mathrm{g}^{-1}\right)\right]$. Drought stress whose effects increase by time can cause protein denaturation and lipid peroxidation and can trigger and accelerate cell corruption [21]. ROS damage cell components by inactivating enzymes. Increased ROS level is the most known indicator of stress. Plants and other organisms developed different mechanisms to cope with this problem. Free radicals cause lipid esterification by starting lipid peroxidation. Membrane damage and ethylene production are also free radicals effects. The capacity of antioxidative defense system is very important of preventing damage of oxidative stress and to detoxify ROS which belong to normal metabolism reactions. Reactive oxygen species are also produced at normal metabolism of alive cells [22] [23] [24].

\section{Acknowledgements}

This study was supported by S.U.B.A.P. (Selcuk University Scientific Research Projects Office) with project coded 13401006. 


\section{References}

[1] R. Ayranc1, B. Sade, "Determination of dent maize (Zea mays L. indentata) varieties that can be cultivated Konya", Journal of Crop Science, vol. 2, pp. 2004.

[2] Anonim, 2015a; www.tuik.gov.tr

[3] G. Camoglu, L. Genc, S. Asık, "Effect of water stress on physiological and morphological parameters of sweet maize (Zea mays saccharata Sturt.)", Journal of Ege University Agriculture Faculty, vol. 48, pp. 141-149, 2011.

[4] Anonim, 2015b; http://derim.com.tr/article/view/5000017042/5000016924

[5] S. Sahin, "Maize production and maize production areas rate in Turkey", Journal of Gazi University Education Faculty, vol. 1, pp. 73-90, 2001.

[6] M. R. Schlemmer, D. D. Francis, J. F. Shanahan, "Remotely measuring chlorophyll content in corn leaves with differing nitrogen levels and relative water content", Agronomy and Horticulture Faculty Publications, pp. 106-112, 2005.

[7] E. Ozdemir, "Effects of seed priming on physiological parameters of bread wheat (Triticum aestivum L.)", M.S. Thesis, Dep. Natural and Applied Sciences, Selcuk University, Konya, Turkey, 2012.

[8] A. Seflek, "Determination of swith grass varieties (Panicum virgatum L.) yield, some morphological, phenological and physiological properties" M.S. Thesis, Dep. Natural and Applied Sciences, Selcuk University, Konya, Turkey, 2010.

[9] L. S. Bates, R. P. Waldren, I. D. Tear, "Rapid determination of free proline for water-stress studies" Plant and Soil, vol. 39, pp. 205-207, 1973. http://dx.doi.org/10.1007/BF00018060

[10] K. V. Madhava, T. V. S. Sresty, "Antioxidative parameters in the seedlings of pigeonpea (Cajanus cajan L. Millspaugh) in response to Zn and Ni stresses" Plant Science, vol. 157, pp.113-128, 2000. http://dx.doi.org/10.1016/S0168-9452(00)00273-9

[11] B. Sade, "Plant physiology". Selcuk University Agriculture faculty Press, 2000, pp.118.

[12] R. A. Fischer, "Selection traits for improving yield potential", Application of physiology in wheat breeding, vol. 13, pp.148-159, 2001.

[13] Anonim,2015c;http://www.researchgate.net/publication/250117569_Wheat_Yield_Progress_Associated_with_Higher _Stomatal_Conductance_and_Photosynthetic_Rate_and_Cooler_Canopies

[14] I. Amani, R. A. Fischer, M. P. Reynolds, "Canopy temperature depression association with yield of irrigated spring wheat cultivars in a hot climate", J. Agron. Crop Sci., vol. 176, pp. 119-129, 1996. http://dx.doi.org/10.1111/j.1439-037X.1996.tb00454.x

[15] F. Giunta, R. Motzo, M. Deidda, "SPAD readings and associated leaf traits in durum wheat, barley and triticale cultivars" Euphytica, vol. 125, pp. 197-205, 2002. http://dx.doi.org/10.1023/A:1015878719389

[16] S. Vartanl1, "Determination of yield and quality properties of some hybrid maize varieties" M.S. Thesis, Det. Natural and Applied Science, Ankara University, Ankara, Turkey, 2006.

[17] L. Szabados, A. Savoure, "Proline: multifunctional amino acid", Cell Press, vol. 15, pp. 89-97, 2009,

[18] P. B. Kavi Kishor, "Regulation of proline biosynthesis, degradation, uptake and transport in higher plants: its implications in plant growth and abiotic stress tolerance", Curr. Sci., vol. 88, pp. 424-438, 2005.

[19] B. Sade, S. Soylu, E. Yetim, "Drought and oxidative stress", African Journal of Biotechnology, vol. 10, pp. 11102$11109,2011$.

[20] M. K. Nikolaeva, S. N. Maevskaya, A. G. Shugaev, N. G. Bukhov, "Effect of drought on chylorophyll content and antioxidant enzyme activities in leaves of three wheat cultivars varying in productivity", Russian Journal of Plant Physioloy, vol. 57, pp. 94-102, 2008.

[21] T. Kalefetoglu, Y. Ekmekci, Y., "Effect of drought stress on plants and mechanisms of resistance", Journal of Gazi University Science Institute, vol. 18, pp. 723-740, 2005.

[22] A. Arora, R. K. Sairam, G. C. Srivastava, "Oxidative stress and antioxidative system in plants", Current Science, vol. 82, pp. 1227-1238, 2002.

[23] R. G. Alscher, J. L. Donahue, C. L. Cramer, "Reactive oxygen species and antioxidants: Relationships in green cells" Physiology Plant, vol. 100, pp. 224-233, 1997. http://dx.doi.org/10.1111/j.1399-3054.1997.tb04778.x

[24] I. Fridovich, I., "Superoxide radical and superoxide dismutase", Annual Review Biochem., vol. 64, pp. 97-112, 1995. http://dx.doi.org/10.1146/annurev.bi.64.070195.000525 